\title{
Battle of the Java Sea: One Event, Multiple Sites, Values and Views
}

\author{
M. R. Manders ${ }^{1,2}$ (D) R. W. de Hoop ${ }^{2}$ (D) S. Adhityatama ${ }^{3}$ - D. S. Bismoko ${ }^{3}$. \\ P. Syofiadisna ${ }^{3} \cdot$ D. Haryanto ${ }^{4}$
}

Accepted: 21 December 2020 / Published online: 28 January 2021

(c) The Author(s) 2021

\begin{abstract}
Three Dutch naval ships, HNLMS De Ruyter, HNLMS Java and HNLMS Kortenaer, were lost during the Battle of the Java Sea on 27 February 1942, claiming the lives of 915 sailors. Although the ships were relocated in 2002, no official action was taken until 2016 when an international diving team from the Karel Doorman Foundation discovered that the warships had disappeared. This created tension between the government of Indonesia and those countries that had lost ships in the archipelago, especially the Netherlands. A three-track cooperation agreement was set up to investigate the disappearance of the three Dutch wrecks with the aim of understanding what had happened, in order to create a better basis for cooperation in the future. The management and protection of shipwrecks from WWII is very complicated, because of the different values that stakeholders attach to them. Only with the proper understanding and consideration of the different values or significance WWII shipwrecks hold for different stakeholders can new ways of managing these complex sites be developed that have long-term effectiveness. This paper argues that different stakeholder groups from both the flag and the coastal state must work together on this issue.
\end{abstract}

Keywords WWII $\cdot$ Shipwrecks $\cdot$ Value $\cdot$ Management $\cdot$ Cooperation

\section{Introduction}

In November 2016, a group of technical divers discovered the disappearance of three Dutch WWII wrecks-HNLMS De Ruyter, HNLMS Java and HNLMS Kortenaer-that sank on the 27 February 1942 during what has become known as the Battle of the Java Sea in Indonesian territorial waters. The large metal shipwrecks had been obviously salvaged from the seabed. How had this happened? Who was to blame? The discovery lead to tensions between the governments of Indonesia and the Netherlands, reflecting the complications that can arise in the management and protection of shipwrecks from WWII because of the different values that stakeholders attach to them. This article discusses the results of a

M. R. Manders

m.r.manders@arch.leidenuniv.nl

Extended author information available on the last page of the article 
three-track investigation that was initiated to mitigate these tensions, taking into consideration different stakeholder values from both the flag and the coastal state. The cooperative investigation represents new ways of managing these complex sites, resulting in long-term effectiveness and a much brighter future in maritime archaeology and heritage management between the two countries (Fig. 1).

\section{Historical Background and Present Context}

On 27 February 1942, the first act of a decisive sea battle took place between the Allied forces of American-British-Dutch-Australian Command (ABDACOM) and the Imperial Japanese Navy. This battle on the Java Sea was the final attempt to prevent the Japanese occupation of the Dutch East Indies. It was an unequal battle between a well-trained and superior Japanese battle fleet and a hastily assembled fleet of relatively ill-equipped and often dated ships of different nationalities. HNLMS De Ruyter, flagship of Dutch Rear Admiral Karel Doorman, HNLMS Java and HNLMS Kortenaer were torpedoed by the Imperial Japanese Navy during the battle. As a result, 915 men on board these ships died. The three Dutch ships were not the only ones lost: ships of several nationalities within the ABDACOM fleet were also sunk, along with a number of Japanese ships. In total, around 2300 lives were lost in the battle. Defeat in this WWII sea battle, the first in which the Netherlands had been involved in almost 150 years, and the engagements in the days that followed meant the loss of the last East-Asian barrier to Japanese dominance and a permanent change in the Kingdom's relations with its overseas colonies in Asia (Dissel 2012, 30). ${ }^{1}$

For a very long time, the exact locations of the three Dutch sunken ships remained unknown. In general, little was said in the Netherlands about WWII in the 'East' (Huis 2019, 220). For Indonesia, the wrecks were a symbol of what had been a very different society under colonial rule. As a result, little was known except the rough locations as mentioned by survivors of the battle and written down in texts such as the memoirs of Lieutenant-Admiral Helfrich (1950). On 1 December 2002, an Australian tech-dive team discovered what they believed were the light cruisers HNLMS De Ruyter and HNLMS Java. These ships, approximately $170 \mathrm{~m}$ and $155 \mathrm{~m}$ in length, were identified on the basis of specific features and photographs were taken. Two years later, in 2004, the same team claimed to have also found the 98 m-long destroyer HNLMS Kortenaer (Fock 2016).

Although the discovery of the sites had been publicly announced and information on the wrecks was available on the Internet, no official report was ever made to either the Dutch or the Indonesian authorities. This is an important issue, as for many years no action was taken by either government. A formal report could have triggered formal cooperation between various ministries in the two countries at that time. Given the circumstances, this did not occur, not least because for a long time the heritage component of these wrecks was not acknowledged.

For several years, the locations were the site of technical dive trips (mainly involving tourists) and commemorative visits on the sea surface (Dissel 2007, 34). In 2008, a dive trip to De Ruyter and Java was recorded on film. The resulting footage showed two wellpreserved wrecks on the seabed. A small number of items were lifted from the wrecks

\footnotetext{
1 For a more detailed description of the Battle in the Java Sea see: Bezemer (1987), Bosscher (1986), Cox (2011), Cox (2014), Doedens/Mulder (2017), Helfrich (1950), Kroese (1945), Nater (1980).
} 
in the years that followed. Artefacts including four bells engraved with the names of $D e$ Ruyter and Java found their way to an auction house in Australia, and later to the Navy Museum in Den Helder, the Netherlands, and Kembang Kuning, the war cemetery in Surabaya, Indonesia. ${ }^{2}$ As far back as 2007, informal discussions took place between the Royal Netherlands Navy and the descendants of the victims about the future of the wrecks and it was hoped that through the signing of international agreements the locations would be protected as war graves (Dissel 2007).

It was not until 2016 that an active field visit was proposed, in preparation for the 75-year commemoration of the Battle of the Java Sea on 27 February 2017. At this time, recently established channels of communication and cooperation between three Dutch ministries-Defence, Foreign Affairs, and Education, Culture and Science-enabled more productive discussions on the future of the sites. These discussions were initiated by a proposed diving expedition, which was to be undertaken by the discoverers of the sites and initiated by the Karel Doorman Fonds (KDF), a Dutch foundation that supports former Navy personnel and has strong ties with the families of the Dutch crew involved in the Battle of the Java Sea. ${ }^{3}$ The sailors who died in the battle were not only born in the Netherlands; a significant number of them came from Java and other Indonesian islands and died protecting the land of their birth against Japanese invasion. The battle is one of profound significance in Indonesian history, especially on a national level, as one of the events that signalled the end of Dutch colonial rule.

The discussions in the Netherlands between the relevant ministries and the KDF regarding the protection and management of the sites and the way this should be handled in relation to the coastal state, Indonesia, soon revealed that there was much more at stake than organizing a diving expedition to the sites. Events in the Dutch East Indies before, during and immediately after WWII are still surrounded by complex emotional sensitivities in both countries (see for example Bij1 2012). Due to a collective sense of shame at losing the battle and regular tensions between the Netherlands and Indonesia regarding their colonial past, the wrecks have not been at the centre of any discussions between the two countries.

Cultural heritage is often characterized by dissonance. It is also true that certain aspects of heritage are contested more visibly at particular moments in time (Huis 2019, 218). In the case of these wrecks, this was true for many years after Indonesia gained its independence. It was an issue that had become too delicate for both parties. The distance between the historical narratives and the cultural archives of the two countries had become too great.

In addition, archaeologists and cultural heritage managers in both countries have only recently become interested in warships from WWII, and so these vessels were not specifically protected by the heritage laws of either Indonesia or the Netherlands or by the UNESCO 2001 Convention. ${ }^{4}$ As a result, no one intervened after the war, when many wrecks in the Netherlands as well as in Indonesia were officially salvaged because they

\footnotetext{
${ }^{2}$ Two of these bells were from De Ruyter and two of them were from Java. One of De Ruyter's bells now hangs in the Kloosterkerk in The Hague. The second bell was placed in the hall of the Command Building in Den Helder. One of Java's bells was placed at the Karel Doorman monument at the Dutch war cemetery Kembang Kuning in Surabaya. The second bell is on display at the National Military Museum in Soesterberg.

3 https://www.kareldoormanfonds.nl/. Accessed 8 October 2020.

${ }^{4}$ For a long time, there was little interest in WWII wrecks outside the field of avocational diving. Until 2012, under Dutch heritage law, there was a cut-off date of 50 years before an object could be considered cultural heritage. In Indonesia, this minimum period of 50 years still applies.
} 


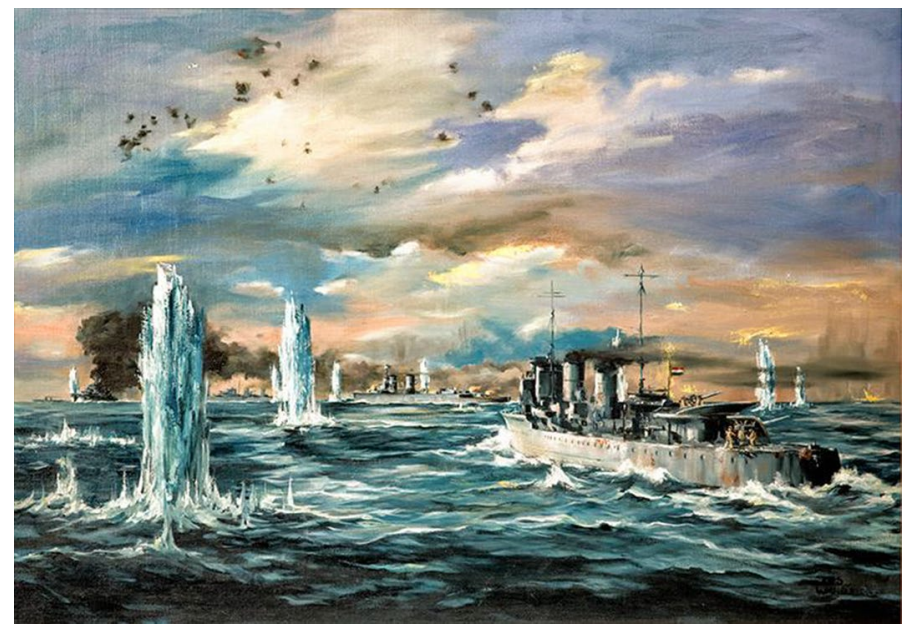

Fig. 1 'Battle of the Java Sea', painting by J. van der Ven, 1970 (Navy Museum Den Helder)

were navigational hazards. Although the battle area in the Java Sea was recognized as a place of remembrance by the descendants, the main commemorative services were held at the war cemetery in Surabaya in Indonesia and the Kloosterkerk (Cloister Church) in The Hague, in the Netherlands. For these reasons, the need to grant these locations the status of cultural heritage sites that need to be assessed, protected and managed was long regarded in both countries as a low priority.

In preparation for the 2017 commemoration, a diving expedition to the sites was organized by the KDF in November 2016. The original plan had been that the expedition should be a joint undertaking by the KDF, the Dutch Ministry of Defence and the Dutch Ministry of Education, Culture and Science. However, ministerial involvement became impossible when the Dutch government's official request for permission for the expedition received no reply from the Indonesian government. The KDF went ahead with the expedition with the team who had already made multiple dives at the wreck sites. For this purpose, MV Empress was hired, a ship the dive team had used on their previous visits to the wrecks. The team also included the son of Rear Admiral Karel Doorman and a film crew. It was during that trip that the divers discovered that the wrecks of De Ruyter and Java had disappeared. At the positions where the ships had lain, there were only large depressions in the seabed and large lumps of clay. Some metal shipwreck fragments were discovered in the area. At the location of what was supposed to be Kortenaer, only a small, heavily corroded fraction of the previously discovered shipwreck remained.

The 2016 expedition found further evidence that other warships lost on the first day of the Battle of the Java Sea had gone missing from their final wrecking sites:

- USS Perch, an American submarine, had been completely removed.

- HMS Exeter had been completely removed. Some human remains were observed, exposed on the seabed.

- HMS Encounter had been almost completely removed. Several small sections remained, the largest of which was $17 \mathrm{~m}$ in length. 
- HMS Electra was the only sunken warship from the Battle of the Java Sea that remained relatively intact, although it had been subject to light partial salvaging over an extended period. The ship was in poor condition and showed signs of advanced corrosion (Fock 2016, 13-19; 24-28). ${ }^{5}$

Although the aim of the expedition had not been to lift any objects from the seabed, these unwelcome findings prompted the team to bring up five items as proof that the expedition had been at the right locations and to help identify the three missing Dutch wrecks. ${ }^{6}$ The divers came to the conclusion that the wrecks had been salvaged and reported this to the KDF in the Netherlands, which in turn notified the Dutch authorities, including the Cultural Heritage Agency of the Netherlands (RCE).

\section{Joint Dutch-Indonesian Investigation}

Dutch authorities discussed the report of the missing wrecks with their Indonesian counterparts. ${ }^{7}$ Since all available information about the discovery and the disappearance of the wrecks had been gathered and recorded by third parties, it was decided that a joint research team of Dutch and Indonesian experts would evaluate the available data. This was part of a three-track research proposal that was jointly set up. ${ }^{8}$ It included

1. Joint verification of the disappearance of the warships.

2. Joint verification of the facts and a legal framework regarding the missing remains of sunken warships.

3. Cooperation on future preservation of maritime war graves and other maritime cultural heritage.

\section{Track 1}

From 6 to 9 February 2017, experts from both countries met in Jakarta to conduct the first track: a joint verification of the status of the shipwrecks of HNLMS De Ruyter, HNLMS Java and HNLMS Kortenaer. The aim was to find out whether the alleged disappearance of the wrecks could be verified and whether the information collected by the divers could be validated. The joint verification involved relevant experts from both countries in fields such as hydrography, underwater archaeology and cultural heritage management, with a view to clear identification of De Ruyter, Java and Kortenaer and the status (i.e. location and condition) of the shipwrecks. The experts were asked to draw their conclusions based

\footnotetext{
${ }^{5}$ Due to the fact that the divers had previously dived at the sites, it had been assumed that no permit would be needed for the dive itself and subsequent filming of the documentary. The lack of a permit became an issue once it was discovered that the wrecks were missing and objects had been removed from the seabed. Under Indonesian law, a permit should have been obtained through Ristekdikti, a lengthy process involving visits to several government ministries.

6 This consisted of one wine bottle, one valve and three shell cases.

7 The meetings were organized through the Ministries of Foreign Affairs from the Netherlands and Indonesia. In total, two Indonesian ministries, the Indonesian Navy (TNI-AL) and three ministries from the Netherlands were involved in the talks.

${ }^{8}$ From the beginning, the three phases of the investigation were called Tracks. In this article, we therefore refer to the three successive stages of the process as Tracks 1, 2 and 3.
} 
on the claims made by the divers and the information they and others had collected and made available. The experts carried out this task using a combination of data sets: video, photographs, multibeam data and the divers' descriptions of the November 2016 expedition, as well as data from earlier dives that were either provided by the divers or retrieved from the Internet.

It was essential that a joint conclusion be reached regarding the current status of the shipwrecks in order to foster mutual understanding and to set out the baselines for further cooperation. Eventually, the experts jointly reached the conclusion that the positions and ship characteristics were fairly consistent with the historical data on the battle, the ships and the circumstances in which they sank. The locations under investigation were identified beyond doubt both as the places where De Ruyter, Java and Kortenaer had sunk and the places where divers had visited the shipwrecks previously. In other words, the shipwrecks had indeed disappeared and had probably been illegally salvaged.

One interesting finding to emerge from the discussions is that De Ruyter and Java were reversed in relation to the positions recorded historically after the battle (Kroese 1945; Helfrich 1950). The analysis of videos, photographs and a low-resolution multibeam recording from the 2016 diving expedition provided convincing evidence of systematic salvage at all three locations (Manders et al. 2017, 31-32). The outcome of the first track resulted in a public report. ${ }^{9}$

\section{Track 2}

The aim of Track 2 was to investigate scenarios of what had happened to the wrecks and by whom. The track also included the determination of legal responsibility and the legal claims of ownership and war graves. From the start of this track, there was an understanding between the two governments that this could well prove to be the most difficult and sensitive part of their collaboration, since the chances of finding those who salvaged the shipwrecks were likely to be very slim, while issues of legal ownership were likely to spark disagreement. Both governments also acknowledged the sensitivities surrounding their differing positions on the subject of war graves.

Based on the data that were gathered, the only conclusions that could be reached at the end of this phase of the joint investigation were that the wrecks had been salvaged using industrial methods and without permission from the Indonesian authorities. The administration of the most prominent harbours was investigated and areas visited where the scrap may have been brought to shore. Also, behind-doors discussions with professional salvors revealed that only large professional equipment could have broken up ships of this construction, lifting their parts to the water's surface from $70 \mathrm{~m}$ depth and shipping them to shore. It was widely known that Chinese salvage companies and salvage companies working on behalf of China had operated in Indonesian waters in the past, both legally and illegally, but - although such companies were a likely culprit- there was no clear evidence to link them to the disappearance of De Ruyter, Java and Kortenaer.

The Indonesian authorities stated that an examination of the harbour books revealed no suspicious activity in the nearest ports of Northeast Java during the period in which the

\footnotetext{
${ }^{9}$ Reports of the joint missions are available online at: https://english.cultureelerfgoed.nl/topics/marit ime-heritage/shipwrecks/dutch-shipwrecks-in-the-java-sea/first-results-of-dutch-indonesian-investigation. Accessed 8 October 2020.
} 
illegal salvaging of these wrecks had presumably been carried out. Illegal and legal salvage operations, many on a large scale, are a common occurrence in Indonesian waters and the wider region (Holmes et al. 2017; Sudaryadi et al. 2012, 17). According to the Indonesian authorities, as far as could be ascertained, no scrap metal from these three Dutch warships had been offered for sale locally (see RCE $2018^{10}$ ).

During the investigation, the media received many leads suggesting that these illegal activities had been conducted with the consent of at least some Indonesian authorities. All of these leads were followed up and none of them proved to be correct. The stories were fuelled by the understandable urge to find the culprits. From a Dutch perspective, the war graves of almost one thousand men had been desecrated. One story in particular, involving eyewitnesses who had seen bones being reburied at a cemetery on East Java, attracted media attention (Kas 2018; Boffey 2018). The bones at the cemetery were investigated by Indonesian and Dutch military identification teams and were found to be the remains of animals. $^{11}$

One remaining contentious issue was the ownership of the wrecks and the items associated with them. According to the Netherlands, Dutch warships - even if they have lain on the seabed for 75 years-still belong to the Netherlands. The sovereignty of such wrecks is supported by the United Nations Convention on the Law of the Sea (1982) and the 2015 Resolution of the Institut de Droit International. The Convention and Resolution state that sunken warships remain the property of their country of origin regardless of where they are found and have sovereign immunity at any time. ${ }^{12}$ Indonesia takes the position that wrecks under the UN Convention on the Law of the Sea enjoy no immunity but fall under the Indonesian legal system (Fig. 2).

Another unresolved issue is the status of war graves (United Nation GA resolution 71/257 (2017) paragraph 314). This status as accorded to warships is primarily based on emotional aspects and ethics, but has no formal legal basis. Although there is an ownership claim, the Netherlands do not have a law or regulation in hand to protect WWII shipwrecks outside its own jurisdiction. The status and protection of WWII shipwrecks therefore depend on the willingness and national legislation of the coastal state where they are found. Furthermore, Indonesia is responsible for the actions of its own citizens (as the Netherlands is for its own citizens), especially when they act under their own flag. As a result, each country is entitled to make its own arrangements regarding the protection of its own inhabitants on the matter of war graves. Due to the complexities involved, the issues of ownership and war graves were not solved within Track 2.

In addition to legal claims, rights and obligations, it should also be mentioned that historical perspectives are many and varied, even in cases where history is viewed as shared heritage, like often is the case with Indonesia and the Netherlands. While two countries may share past events and their physical remnants, they may experience and interpret them very differently. These different perspectives - agreeing to disagree on certain aspects of history-needed to be recognized before the last track could be established. This position

\footnotetext{
${ }^{10}$ https://english.cultureelerfgoed.nl/topics/maritime-heritage/publications/publications/2017/01/01/repor t-of-the-dutch-shipwrecks-in-the-java-sea. Accessed 8 October 2020.

11 An on-site investigation by the Salvage and Identification Service of the Royal Netherlands Army only produced animal bone material. See: https:/www.rijksoverheid.nl/documenten/kamerstukken/2018/03/16/ kamerbrief-over-de-bevindingen-van-het-onderzoek-naar-verdwenen-scheepswrakken-in-de-javazee. Accessed 8 October 2020.

12 Article 29 of UNCLOS 1982: http://www.un.org/depts/los/convention_agreements/texts/unclos/part2 .htm. Accessed 8 October 2020.
} 
therefore allowed room in Track 2 for differing views on what merits protection and preservation and what does not (RCE 2018).

\section{Track 3}

Track 3 centres on active cooperation in underwater cultural heritage (UCH) management between the Netherlands and Indonesia and is designed to prevent an illegal salvaging incident like this one from ever happening again. The scope of this track is much wider than law enforcement or the focus on WWII wrecks alone. This track represents the beginning of a renewed cooperation between the two countries in underwater and maritime cultural heritage research and management in the widest context. ${ }^{13}$ The aim is to accept and respect different points of view and, through this acceptance, to cooperate within projects to learn from each other not only as scientists but also as societies.

An important first step towards future cooperation was taken in February 2017. During a visit to Indonesia by the then Dutch Minister of Education, Culture and Science, Jet Bussemaker, a Memorandum of Understanding was signed with the Indonesian Ministry of Culture with a view to establishing cultural cooperation. One of the specific aims contained in this Memorandum (number 8 to be precise) is to intensify cooperation in maritime heritage management, as well as the protection of shared cultural heritage. ${ }^{14}$ Another step, taken at the request of the Netherlands, was that the three wreck locations of De Ruyter, Java and Kortenaer should be marked as 'historic shipwrecks' on the nautical maps of Indonesia from 7 July 2017. This means that no diving, anchoring or fishing is allowed at these locations. From that time, in effect, the sites would be officially recognized as lieux de memoire, or sites of commemoration. This was one of the wishes expressed by the descendants in both the Netherlands and Indonesia.

Also, part of Track 3 included a site visit to the three Dutch wrecks. In June 2019, the International Programme for Maritime Heritage of the Cultural Heritage of the Netherlands (RCE) together with PUSLIT ARKENAS (Pusat Penelitian Arkeologi Nasional) worked for 10 days at the locations in the Java Sea to establish the extent of the salvaging activities that had been carried out on site. Prior to this fieldwork, a Letter of Intent was drawn up between the two countries for the management of the three wreck sites as an addition to the Memorandum of Understanding signed in $2017 .^{15}$

\section{A Joint Site Visit to the Wrecks}

The aim of the 2019 fieldwork was to map systematically the seabed at the locations where the three Dutch warships had once lain. This research involved an assessment to obtain

\footnotetext{
13 In the past, Indonesia and the Netherlands have undertaken joint activities in maritime archaeological research and management, including training through the UNESCO foundation courses (Manders and Underwood 2012).

$14 \mathrm{https}: / /$ maritime-heritage.com/files/moucultuurnederlandindonesieenggetekend2pdf. Accessed 8 October 2020 .

15 In the Netherlands, the Ministry of Education, Culture and Science, the Ministry of Defence and the Ministry of Foreign Affairs worked together intensively to make this project happen. In Indonesia, the project was supported by KEMLU and the Embassy of the Netherlands in Jakarta. https://english.cultureele rfgoed.nl/topics/maritime-heritage/international-projects/indonesia/cooperation-agreement. Accessed 8 October 2020.
} 


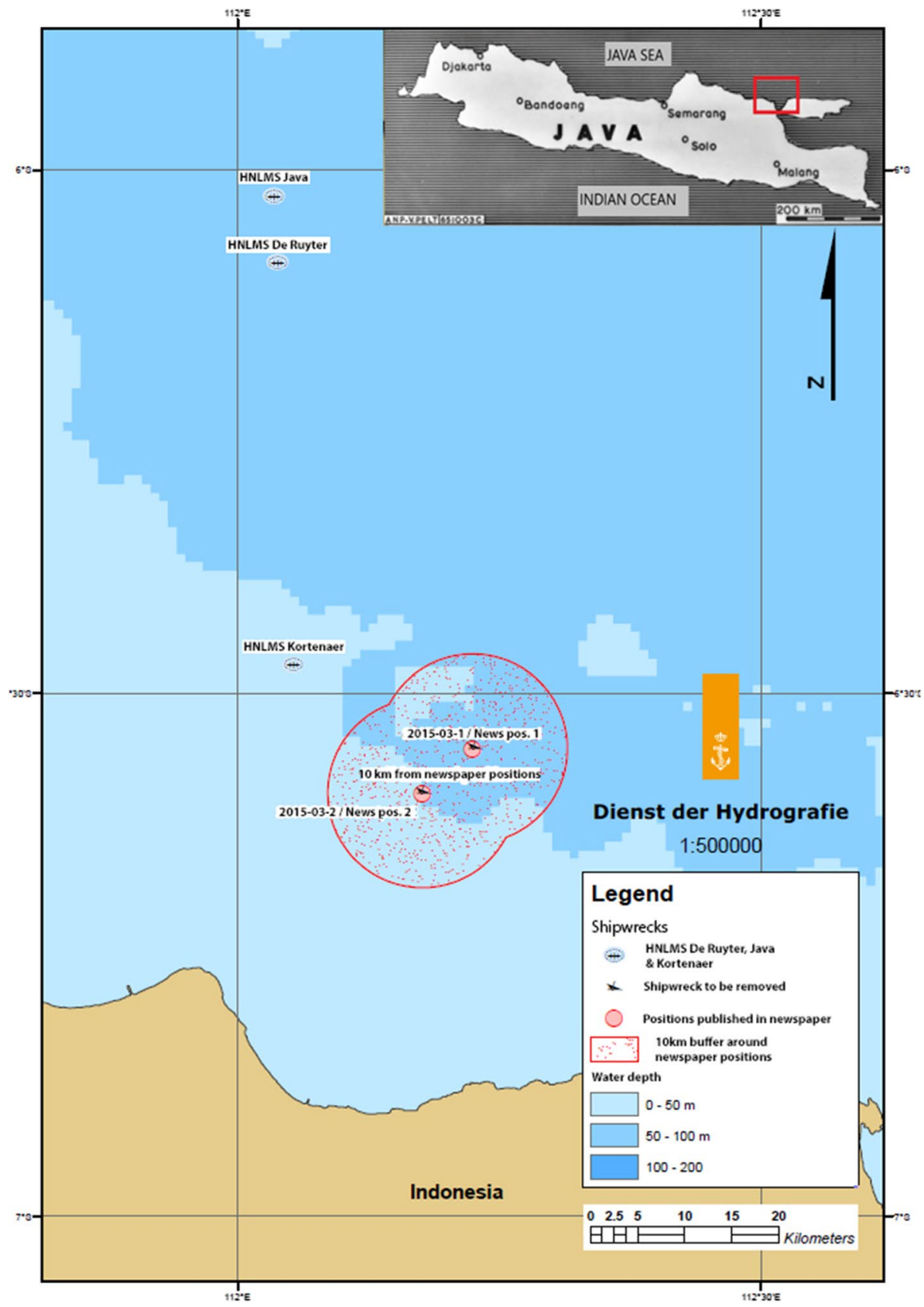

Fig. 2 Locations of the three Dutch warships and positions reported in the media. $\odot$ Dienst der Hydrografie (Hydrographic Service)

a better view of the material still present and the potential of the locations in terms of research, protection and/or commemoration. This research should result in a management plan for the sites, one that will serve as an example for other sites in Indonesian waters, 
whether or not they involve Dutch ships. This management will be based on the format currently being taught in the UNESCO foundation courses (Manders and Underwood 2012).

The fieldwork consisted of a non-intrusive field assessment with remote sensing. The research ship Baruna Jaya II and a specialized crew was hired for the expedition. ${ }^{16}$ The data were collected systematically with a view to providing a baseline study for future management. The documentation of the seabed was conducted with the following remote sensing techniques:

- Magnetometer ${ }^{17}$

- Multibeam echosounder ${ }^{18}$;

- ROV (Remotely Operated Vehicle) ${ }^{19}$;

- Side scan sonar ${ }^{20}$;

- Sub-bottom profiler. ${ }^{21}$

The archaeological work was carried out according to UNESCO standards specified in the Manual for Activities Directed at Underwater Cultural Heritage: Guidelines to the Annex of the UNESCO 2001 Convention (Maarleveld et al. 2013). Hydrographical data were acquired according to the S-44 standards for hydrographic surveys set by the International Hydrographic Organization (IHO). ${ }^{22}$ This enabled better positions and depth readings to be collected for the official hydrographic maps.

\section{Fieldwork Results}

On all three wreck sites, the first step was to map the site with a multibeam echosounder. Using the multibeam data, a plan was then drawn up to map the site in greater detail with side scan sonar, a magnetometer, a sub-bottom profiler and finally to film the site with equipment mounted on a ROV to obtain visual evidence of the disturbances on and within the seabed (Fig. 3).

\section{HNLMS De Ruyter}

The fieldwork revealed more remains of De Ruyter at the wreck site than had been expected on the basis of the report made by the 2016 dive team and their multibeam data. Large pieces of the ship, measuring up to approximately $10 \mathrm{~m}$ in length, were still visible on the seafloor, with additional smaller debris scattered around them. No items that could be related to an individual (e.g. clothing, memorabilia) were spotted while mapping the site with the ROV. A few sections of the ship were also covered with sand and clay. The entire site was turned over during the illegal salvaging and showed signs of severe disturbance. This could be deduced from the deep trenches, the large lumps of clay on the surface of the

\footnotetext{
16 Indonesian state-owned Agency for the Assessment and Application of Technology (BPPT).

17 Geometric 882.

18 Elac Seabeam 1050D, $180 \mathrm{kHz}$ MBES.

19 Seaeye FALCON DR.

20 Edgetech 4200FS.

21 SBP Boomer, frequency $1-4 \mathrm{kHz}$, SBP depth $1 \mathrm{mtr}$, gain 5-15 dB.

22 https://iho.int/uploads/user/pubs/standards/s-44/S-44_Edition_6.0.0_EN.pdf. Accessed 8 October 2020.
} 
seabed and lengths of thick rope that had probably been used to lift parts of the wreck. At a cautious estimate, less than $5 \%$ of the wreck is still present on and within the seabed.

\section{HNLMS Java}

At the location of Java, much less was visible on the seafloor. Shapes of metal material were visible just below the sandy sediment. Holes could also be seen, indicating that sand had fallen through gaps in the buried material. No personal items were spotted while mapping the site with the ROV, but many large $15 \mathrm{~cm}$ cartridge cases were visible on the seafloor. As with De Ruyter, the entire site showed signs of disturbance, indicating that it was turned over during the illegal salvage. In this case too, it is estimated that a maximum of $5 \%$ of the ship still lies on the seabed (Fig. 4).

\section{HNLMS Kortenaer}

At the location of Kortenaer, a large section of the ship was found on the seabed, with its construction elements still relatively intact. This was also visible on the video made during the 2016 diving expedition. The height of this section was up to $10 \mathrm{~m}$ in places. Although quite substantial, the metal was very badly damaged and had been visibly dented by the illegal salvage operation. Very few other parts were found around the ship's main section, which makes up between 10 and $15 \%$ of the total wreck. This corresponds with the estimate made by the dive team in 2016 . No personal items were spotted while mapping the site with the ROV.

\section{General Observations}

Lengths of thick rope were observed at all three sites, particularly in relation to large thick steel plates. There are two possible explanations for this: the rope could be the remains of old fishing nets that became entangled in the wreck prior to the salvaging, or it is rope that was used during the salvage operation. In some places, it appeared to be tied around the steel plates. A fishing net was seen alongside a section of rope at one location only. Despite widespread sightings of rope and fishing nets entangled with the wrecks during earlier expeditions, there is a strong suspicion that the rope seen during the fieldwork was used by the salvagers and fell to the seafloor as they attempted to lift parts of the wreckage. Recovering lost parts that had accidently dropped on the seabed would have been difficult without proper equipment and perhaps the salvagers did not think it was worth the additional effort.

\section{Future Activities}

The three wreck locations have been marked as 'historic shipwrecks' on the nautical maps of Indonesia since 7 July 2017, and their existence and importance are now recognized. However, at present these are only point locations. They will have to be converted into larger zones based on the field research carried out in 2019, and the wreck sites specifically marked as places of remembrance. This will allow the sites to be opened up for specific commemorative activities. The Indonesian government is currently working on this zoning 


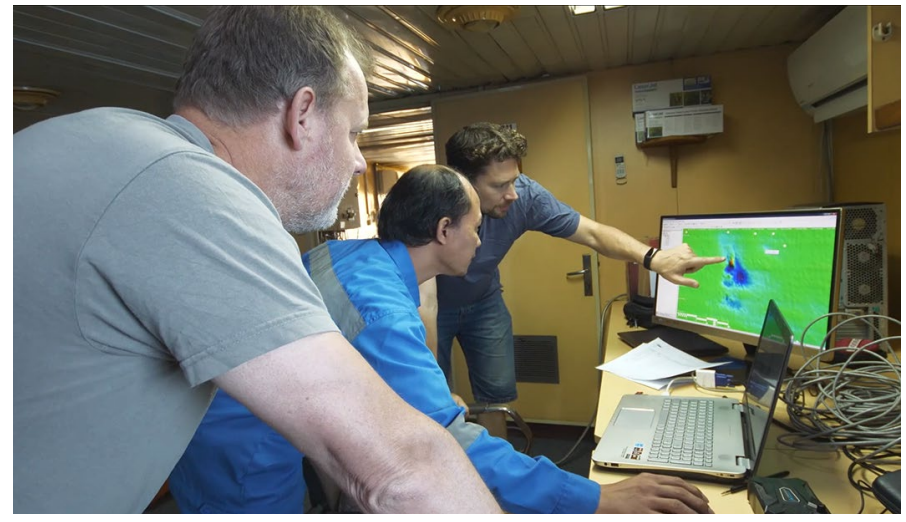

Fig. 3 After mapping the site with multibeam, plans are being drawn up to map the site using other equipment. (C) RCE

Fig. 4 Multibeam image of the location where the wreck of HNLMS Java lay. It clearly shows a deepening in the seabed where the hull had once been. (C) Joint Dutch-Indonesian Investigation Team

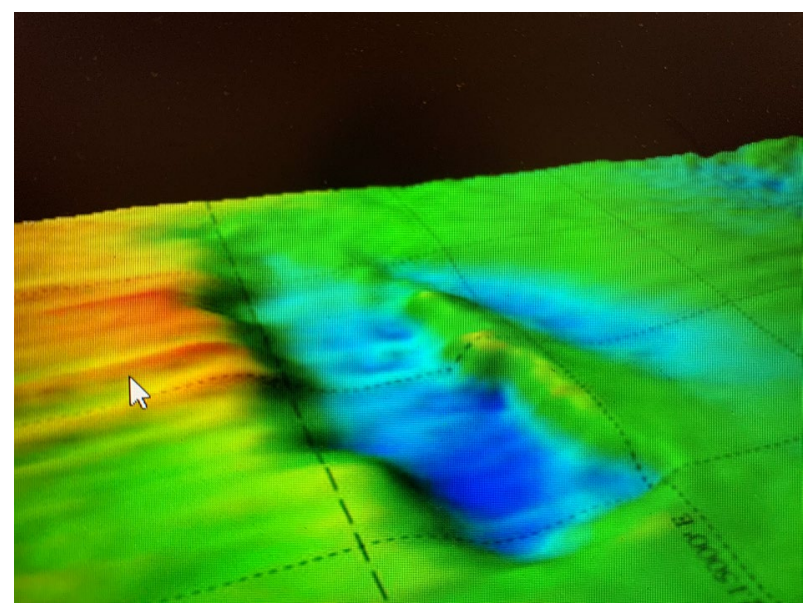

of the sites. ${ }^{23}$ This joint management approach based on mutual respect is a template that may also be used in connection with other wrecks in the area.

\section{The Economic Value of Metal from Wrecks WWII}

The three Dutch wrecks were illegally salvaged and this seems to be an increasing problem with metal shipwrecks. WWII shipwrecks in particular are vanishing at an alarming rate. In recent years Australian, American, British, Dutch and Japanese warships have all been illegally salvaged (Campbell 2016; Holmes 2016, 2017; Holmes et al. 2017; Meskin 2014; Wargadiredja 2017). These shipwrecks are not only important historical sites, but in many cases also war graves.

${ }^{23}$ This Java Sea Zoning Plan will be imposed by means of a presidential decree. 
The salvagers view the warships as a source of income, a view based on the value of the metal they contain. Low-background steel is any steel produced prior to the detonation of the first atomic bombs in the 1940s and 1950s. As the three Dutch warships sank before the Trinity test and the atomic bombing of Hiroshima and Nagasaki in 1945, the steel they are made of is low-background steel (i.e. it is not irradiated). These and subsequent nuclear tests during the early years of the Cold War led to radioisotopes entering the atmosphere and increased background radiation levels around the world. During steel production, these radioisotopes end up in the steel. Shipwrecks have therefore become a valuable source of highly desirable low-background steel, which is difficult to find anywhere else. For the majority of purposes, it does not matter whether or not steel is irradiated, but there are devices for which 'radiation neutral' steel is required. These include radiation gauges, medical equipment and sensors used in aerospace (Allen 2017; Miles 2017; Perez Alvaro 2013, 41-43).

Low-background steel from the wrecks of WWI and WWII warships is therefore worth considerably more than regular steel. This makes the wrecks likely targets for salvagers. In addition to steel, the wrecks are also a source of other valuable metals such as phosphor bronze (the propellers), brass, copper and high-grade aluminium. Seeing shipwrecks as an economic source is not new, nor is it limited to one part of the world. The illegal salvaging of WWI and WWII wrecks has also occurred in South America, Europe and other parts of Asia. It is a big problem in Malaysia, for example. Two Dutch submarines in Malaysian waters have also fallen prey to salvaging activities, while two more are believed to have undergone the same desecration. ${ }^{24}$ In 2011, the British WWI shipwrecks HMS Aboukir, HMS Hogue and HMS Cressy were salvaged off the Dutch coast. ${ }^{25}$ In 2016, it was reported that a Dutch-based marine salvage company was removing material from the wreck site of HMS Queen Mary in the North Sea. It is very likely that the same company also salvaged several other ships that sank during the Battle of Jutland in WWI. ${ }^{26}$

If large-scale illegal exploitation of our maritime past is to be stopped, cooperation between countries is essential. Another preventive measure would be to reach out to international companies where there is demand for these metals and raise their awareness of the origin of the resources.

\section{Protection of Warship Wrecks}

This is not the first time that wrecks have been salvaged in the Java Sea. In 2013, it emerged that HMAS Perth had fallen prey to illegal salvaging. A report by a team from Indonesia's Ministry of Education and Culture confirmed in 2014 that part of the stern of this wreck had been salvaged illegally (Adhityatama 2014). Meanwhile, a 2014 study of USS Houston revealed that this warship also showed signs of systematic salvaging. According to Besser et al. (2013), the Australian authorities tried to keep the salvaging of HMAS Perth a secret, fearing potential diplomatic fallout between Australia and Indonesia. In response to media reports about illegal salvaging activities on HMAS Perth in 2017, Indonesia's National

\footnotetext{
${ }^{24}$ https://english.cultureelerfgoed.nl/topics/maritime-heritage/international-projects/malaysia/dutch-subma rines-in-malaysian-and-vietnamese-waters. Accessed 8 October 2020.

${ }^{25}$ http://www.dailymail.co.uk/news/article-2042294/Dutch-vessels-ransack-sunken-British-warships-conta ining-bodies-1-500-sailors-scrap-metal.html. Accessed 8 October 2020.

26 https://thepipeline.info/blog/2016/05/22/exclusive-named-the-salvage-company-which-looted-jutlandwar-graves-as-mod-fails-to-act/. Accessed 8 October 2020.
} 
Research Centre for Archaeology (PUSLIT ARKENAS) and the Australian National Maritime Museum (ANMM) conducted a research project on HMAS Perth and discovered that only $40 \%$ of the wreck was still left on the seabed. A recommendation report was then drafted to the Government of Indonesia which resulted in the protection of HMAS Perth under a Maritime Conservation Area (KKM) signed by Indonesia's Minister of Maritime Affairs and Fisheries (Hosty et al. 2018). At present, an agreement between Indonesia and the USA is underway to protect USS Houston by making it a Maritime Conservation Area.

In 2010, Indonesia also instituted Cultural Heritage Act No. 11 to protect and preserve $\mathrm{UCH}$ at national level. To date, however, no underwater archaeological site has been designated a site of national heritage. The main reason for this is the lack of financial and human resources needed to manage such sites responsibly. Warships, especially WWII warships, are subject to additional complications due to the ongoing discussion about ownership by the flag state. ${ }^{27}$ The protection of $\mathrm{UCH}$ is therefore another area in which cooperation between countries is key. ${ }^{28}$

\section{A Change in Attitude Between the Netherlands and Indonesia}

After the discovery of the disappearance of the three Dutch shipwrecks in November 2016, the Dutch government reached out to the Indonesian government, spurred on by public indignation in the Netherlands. The ensuing diplomatic talks were initially marred by distrust on both sides but the long-term, three-track approach outlined above led to a better understanding and a joint strategy. Some issues have yet to be resolved but they are now at least subject to discussion. It should be noted that such difficulties are not uncommon (and may even be inevitable) between countries whose approaches to heritage and national historical discourses not only differ but are also set against a background of colonialism. Given this situation, it is only logical that in many cases a significance assessment of a site would expose a difference in priorities. However, as Huis (2019) mentions, the aim of post-colonial thought should be to rethink distinctions, not in order to dissolve them but to create new conversations (Huis 2019, 217). Different views therefore need to be discussed and solutions should be sought in a spirit of collaboration. In the end, this should form the basis for the long-term management of these-and other-historical sites.

Indonesia has a huge task on its hands. As an island nation, it has an extensive coastline, vast stretches of territorial waters and not enough capacity to govern its seas intensively. Indonesia needs assistance with this aspect of law enforcement and given that maritime regulations are a worldwide issue, more countries should be prepared to play their part. However, law enforcement is not the only aspect of UCH management and so, as part of Track 3, the Netherlands and Indonesia will also cooperate in other areas: educating new maritime archaeologists, raising awareness among targeted stakeholder groups such as divers and source communities, in situ protection, and sound archaeological research in order to set the right standards and show the potential of such research. A place of remembrance to commemorate the Battle of the Java Sea-an event of profound significance to both countries-will also be erected on land in the coming years. It has become clear that

\footnotetext{
27 The Netherlands also continues to claim the ownership of VOC, WIC and Admiralty ships, see: https:// english.cultureelerfgoed.nl/topics/maritime-heritage/shipwrecks (accessed 16-07-2020).

${ }^{28}$ In Indonesia, the discussion on ratifying the UNESCO Convention for the Protection of the Underwater Cultural Heritage (Paris 2001) is very much alive, although an implementation is not foreseen for the near future.
} 
only by keeping the memory of the event alive (from different perspectives) and by establishing coordinated cooperation between countries and their different stakeholders, can we stop the illegal salvaging of historic shipwrecks (Fig. 5).

\section{Conclusion}

In 2016, it emerged that the wrecks of three Dutch WWII warships-HNLMS De Ruyter, HNLMS Java and HNLMS Kortenaer — had been illegally salvaged. This caused a public outcry in the Netherlands and sparked diplomatic tensions between the Netherlands and Indonesia. The friction and distrust between the two countries has been mitigated through a series of joint actions in which representatives of both governments came together to investigate what could have happened to the wrecks. A three-track approach was established, consisting of a first track to verify the findings of the original dive team, a second track to investigate the facts of what had occurred and who should be held responsible, and a final track focusing on future cooperation to prevent such occurrences ever happening again.

The first track clearly confirmed the observations made by the technical dive team. Positions were correct and the holes in the ground on the multibeam recordings, backed with films and photos of the areas, showed clearly the disappearance of the $170 \mathrm{~m}-, 155 \mathrm{~m}$ - and $110 \mathrm{~m}$-long ships. The second track, dealing with the issue of culpability, turned out to be too complex to produce a solution. Indeed, the wrecks were clearly salvaged and there are some indications on how this was done, but who did this remains unknown. However, this second track was a necessary phase in enabling both countries to arrive at a greater understanding of each other's concerns and to proceed to the last track, which centres on mutual cooperation.

Within Track 3, many achievements have been reached. In 2019, a fieldwork expedition was organized to the locations of the three shipwrecks to record what was left on the seabed. Although little remains of the three vessels, enough elements are still visible to allow the sites to serve as a place of remembrance. The locations are now legally protected by the Indonesian government.

The next step is to ensure the continued commemoration of this historic event in ways that enable differences in perspective to enrich our common past and historical narrative. Differences should be discussed, debated and learnt from. A place of remembrance where visitors can experience what the battle and its heritage mean to both countries, a place that honours the diaspora of history, will be a major step forward. The two countries are working towards these ends. Also, those industries that are in need of low-background steel will be contacted in order to make them understand what the demand this particular 'raw' material does to these war graves.

The Indonesian-Dutch cooperation with regard to the missing ships in the Java Sea has laid the foundation for further cooperation in maritime and $\mathrm{UCH}$ management. A series of events that threatened to widen the distance between two countries has now created a basis for common understanding and respect for differing interpretations of a shared past. We therefore strongly believe that countries working together in the management of the UCH in general creates understanding, which in principle is one of the best ways to protect this valuable resource. 
Fig. 5 Indonesian crew on Baruna Jaya II during the 2019 expedition

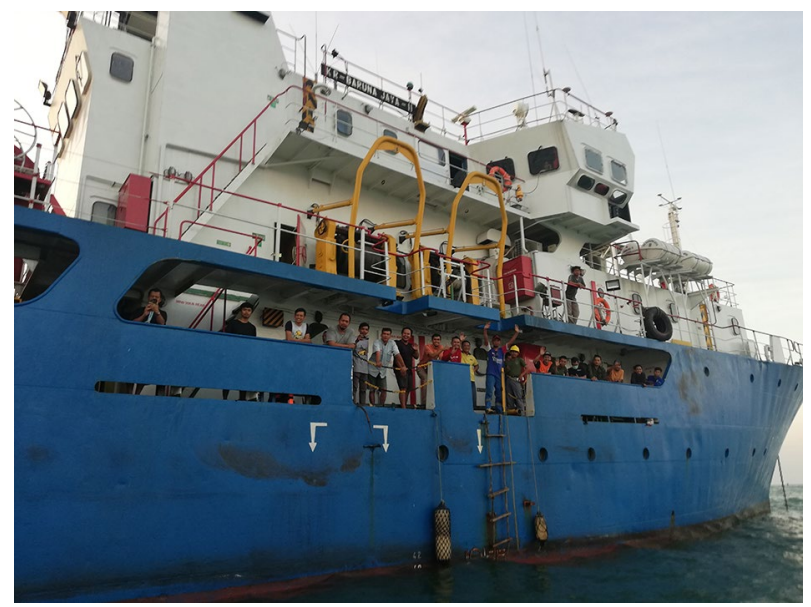

Acknowledgements The illegal salvaging of WWII wrecks is a delicate international issue. Researching the three missing Dutch wrecks in the Java Sea has not been an easy task and we would therefore like to thank all those involved. Each part of the jigsaw puzzle has been of vital importance. Unfortunately, it is impossible to mention every individual by name. Specific thanks go to the ministries of Foreign Affairs, Defence, Education and Culture, BPPT, Foreign Research Permit Ristekdikti, BRIN as well as experts in the field of WWII ship construction, the Karel Doorman Fonds, the dive team that discovered the wrecks, the journalists who brought these issues to the attention of their readers, most notably those from De Telegraaf, The Guardian and Tirto. Last, but certainly not least, we would like to express our appreciation to the descendants of those who lost their lives in the Battle of the Java Sea. It must have been extremely hard for them to be constantly confronted with the desecration of their ancestors' final resting place.

Open Access This article is licensed under a Creative Commons Attribution 4.0 International License, which permits use, sharing, adaptation, distribution and reproduction in any medium or format, as long as you give appropriate credit to the original author(s) and the source, provide a link to the Creative Commons licence, and indicate if changes were made. The images or other third party material in this article are included in the article's Creative Commons licence, unless indicated otherwise in a credit line to the material. If material is not included in the article's Creative Commons licence and your intended use is not permitted by statutory regulation or exceeds the permitted use, you will need to obtain permission directly from the copyright holder. To view a copy of this licence, visit http://creativecommons.org/licenses/by/4.0/.

\section{References}

Adhityatama S (2014) Survey of historical shipwreck of HMAS Perth in Banten Bay, Indonesia. Varuna: J Arkeol Bawah Air 8:83-89

Allen M (2017) Why do we build medical scanners from sunken battleships? http://www.sciencemadesimp le.co.uk/curriculum-blogs/engineering-blogs/why-do-we-build-medical-scanners-from-sunken-battl eships. Accessed 8 Oct 2020

Besser L, Oakes D, Hermant N (2013) HMAS Perth: WWII warship grave stripped by salvagers. http:// www.abc.net.au/news/2013-12-13/outrage-as-warship-grave-stripped-by-salvagers/5156320. Accessed 8 Oct 2020

Bezemer KWL (1987) Zij vochten op de zeven zeeën. Zeist

Bijl P (2012) Colonial memory and forgetting in the Netherlands and Indonesia. J Genocide Res 14(3-4):441-461

Boffey D (2018) Bodies of second world war sailors in Java Sea 'dumped in mass grave'. https://www.thegu ardian.com/world/2018/jan/22/bodies-of-second-world-war-sailors-in-java-sea-dumped-in-mass-grave. Accessed 8 Oct 2020 
Bosscher PM (1986) De Koninklijke Marine in de Tweede Wereldoorlog deel 2. Franeker

Campbell P (2016) Wartime shipwrecks are being illegally salvaged. Are we powerless to stop it? https:// www.theguardian.com/science/blog/2016/dec/20/can-anything-be-done-to-stop-the-vanishing-wwiishipwrecks-of-java. Accessed 8 Oct 2020

Cox J (2011) A turn too far: reconstructing the end of the battle of the Java Sea. n.p

Cox J (2014) Rising sun, falling skies: The disastrous Java Sea campaign of World War II. New York

Dissel AMC van (2007) 65 jaar na de Slag in de Javazee. Marineblad March 2007:32-34

Dissel AMC van (2012) Uit de kluis van de Hr. Ms. De Ruyter. Marineblad February 2012:30-34

Doedens A, Mulder L (2017) Slag in de Javazee. Oorlog tussen Nederland en Japan. Zutphen

Fock AWH (2016) Report—survey of naval wreck sites Java Sea 2016. Melbourne

Helfrich CEL (1950) Memoires. Eerste deel. De Maleise barrière. Amsterdam/Brussel

Holmes O (2016) British second world war shipwrecks in Java Sea destroyed by illegal scavenging. https:// www.theguardian.com/world/2016/nov/16/british-second-world-war-ships-illegal-scavenging-java-sea. Accessed 8 Oct 2020

Holmes O (2017) Images reveal three more Japanese WWII shipwrecks torn apart for scrap. https://www. theguardian.com/world/2017/feb/09/images-reveal-three-more-japanese-wwii-shipwrecks-torn-apart -for-scrap. Accessed 8 Oct 2020

Holmes O, Ulmanu M, Roberts S (2017) The world's biggest grave robbery: Asia's disappearing WWII shipwrecks. https:/www.theguardian.com/world/ng-interactive/2017/nov/03/worlds-biggest-grave -robbery-asias-disappearing-ww2-shipwrecks. Accessed 8 Oct 2020

Hosty K, Hunter J, Adhityatama S (2018) Death by a Thousand Cuts: an archaeological assessment of souveniring and salvage on the Australian cruiser HMAS Perth (I). Int J Nautical Archaeol 47(2):281-299

Huis I van (2019) Chapter 8. Contesting cultural heritage: decolonizing the Tropenmuseum as an Intervention in the Dutch/European memory complex. In: Lähdesmäki T, Passerini L, Kaasik-Krogerus S, Huis I van (eds) Dissonant heritages and memories in contemporary europe. Palgrave studies in cultural heritage and Confict Open Access. pp 215-249

Kas A (2018) De botresten gingen in plastic zakken. Zijn ze van Nederlandse oorlogsslachtoffers? https ://www.nrc.nl/nieuws/2018/01/30/de-botresten-gingen-in-plastic-zakken-a1590263. Accessed 8 Oct 2020

Kroese A (1945) Neerland's Zeemacht in Oorlog. London

Maarleveld TJ, Guérin U, Egger B (2013) Manual for activities directed at underwater cultural heritage. Guidelines to the Annex of the UNESCO 2001 Convention. UNESCO, Paris

Manders M, Underwood C (2012) Training manual for the UNESCO foundation course on the protection and management of underwater cultural heritage in Asia and the Pacific. UNESCO, Paris

Manders MR, Hoop RW de, Adhityatama S, Barten WA, Budi Utomo B, Dwiyana O, Kusno A, Rechar J, Tahir Z (2017) Joint verification of the location and condition of Hr.Ms. De Ruyter, Java and Kortenaer, 6 to 9 th of February 2017. Jakarta

Meskin S (2014) Legal status of warship wrecks from World War II in Indonesian territorial waters (incident of H.M.A.S. Perth commercial salvaging), Sarjana Ilmu Hukum Agustus 2014. http://hukum .studentjournal.ub.ac.id/index.php/hukum/article/view/671. Accessed 8 Oct 2020

Miles K (2017) The thieves who steal sunken warships, right down to the bolts. https://www.outsideonline. com/2168646/how-does-entire-shipwreck-disappear-bolts-and-all. Accessed 8 Oct 2020

Nater JP (1980) Koers 300 vaart 25. De slag in de Javazee. Haarlem

Perez Alvaro E (2013) Experiments on Particle Physics Using Underwater Cultural Heritage: The Dilemma, Rosetta 13.5:40-46. http://www.rosetta.bham.ac.uk/Colloquium2013/perezalvaro.pdf. Accessed 8 Oct 2020

RCE (2018) Public summary report of the joint expert meeting on the appreciation (track II) of the Dutch shipwrecks in the Java Sea. https:/english.cultureelerfgoed.nl/topics/maritime-heritage/publications/ publications/2017/01/01/report-of-the-dutch-shipwrecks-in-the-java-sea. Accessed 2 Nov 2020

Sudaryadi A, Wahjudin J, Manders M (2012) Het beheer van het maritiem Erfgoed in Indonesië. Vitruvius 18, January 2012, pp 14-20

Wargadiredja AT (2017) Pirates Are Looting Sunken WW2 Boats Off The Coast of Indonesia For Scrap. https://www.vice.com/en_id/article/pirates-are-looting-sunken-ww2-boats-off-the-coast-of-indonesiafor-scrap-metal. Accessed 8 Oct 2020

Publisher's Note Springer Nature remains neutral with regard to jurisdictional claims in published maps and institutional affiliations. 


\section{Authors and Affiliations}

M. R. Manders ${ }^{1,2}$ (D) R. W. de Hoop ${ }^{2}$ D . S. Adhityatama ${ }^{3}$ - D. S. Bismoko ${ }^{3}$. P. Syofiadisna ${ }^{3} \cdot$ D. Haryanto ${ }^{4}$

R. W. de Hoop

r.de.hoop@cultureelerfgoed.nl

S. Adhityatama

shinatriaadhityatama@gmail.com

D. S. Bismoko

bismoko@gmail.com

P. Syofiadisna

syofiadisna@gmail.com

D. Haryanto

haryanto@gmail.com

1 Faculty of Archaeology, University of Leiden, Leiden, The Netherlands

2 Cultural Heritage Agency of the Netherlands (RCE), Smalle Pad 5, 3811 MG Amersfoort, The Netherlands

3 Pusat Penelitian Arkeologi Nasional, Jakarta 12510, Indonesia

4 Badan Pengkajian dan Penerapan Teknologi, Jakarta 10340, Indonesia 